\title{
Central Bank Independence Revisited
}

\author{
Carl E. Walsh ${ }^{1}$
}

\begin{abstract}
The recent financial crisis has drawn attention to the interactions between monetary and fiscal policies and their potential implications for central bank independence. I focus on aspects of these interactions. First, is central bank independence meaningless with fiscal acquiescence? And does central bank independence threatens potential gains from monetary and fiscal policy coordination?
\end{abstract}

Keywords: central bank independence, monetary policy.

\section{Introduction}

Twenty years ago, the Reserve Bank of New Zealand Act of 1989 launched an era of central bank reforms that generally had two dimensions. First, the objectives of monetary policy were clarified, usually through the adoption of inflation targeting. Second, the relationship between the central bank and the fiscal authority was altered to give more operational independence to the central bank. Both aspects of reform were clear in the case of the Reserve Bank of New Zealand; during the 1990s, the Reserve Bank of Australia also clarified its policy objectives by adopting inflation targeting, and the bank has, in joint statements with the government, most recently in December 2007, made clear its independence to conduct policy in ways consistent with achieving its objectives.

This combination of clear objectives and operational independence was designed to address the failings of monetary policy during the previous two decades when inflation rates in many countries had been allowed to rise to undesirable levels. The intellectual and empirical victory of Milton Friedman's argument that the long-run Phillips curve was vertical and that sustained inflation was ultimately a monetary phenomenon provided the underpinnings for establishing policy frameworks in which achieving low average inflation was the primary task of a central bank.

But while central banks could control inflation, they had failed to do so in the 1970s. A common explanation for high inflation, at least in the academic literature, drew on the insights of Kydland and Prescott (1977) concerning the time inconsistency of optimal commitment policies. ${ }^{2}$ This diagnosis leads naturally to an examination of the incentives faced by policy-makers and a search

\footnotetext{
${ }^{1}$ University of California

${ }^{2}$ An influential approach to dealing with the inflation bias was provided by Rogoff (1985) who showed that a central banker who valued inflation stability more than society as a whole could lead to improved outcomes. While he assumed the central bank was given complete independence, Lohmann (1992) showed how outcomes could be further improved if the government overrode the central bank in the face of extreme shocks. For surveys of the inflation bias problem, see Persson and Tabellini (1990), Cukierman (1992) or Walsh (2010, chapter 7). For the question of whether the Reserve Bank Act was an optimal contact, see Walsh (1995a,b), while central bank independence is discussed in Walsh (2008).

JEL classifications: E50, E58

Correspondence: Carl E. Walsh, Department of Economics, University of California, UCSC, 1156 High Street, Santa Cruz, CA 95064, USA. Email: walshc@ucsc.edu
} 
for institutional structures that might support or mimic the outcomes that would be achieved under commitment. Getting incentives right could take the form of making clear what the objectives of the central bank were supposed to be, and then ensuring that central banks had the tools to achieve those objectives.

If one source of perverse incentives came from political pressures, often related to the desire for short-run expansions timed to coincide with elections, a need to finance budget deficits or simply a wish by central bankers to be reappointed, then insulation from the political process, protection against pressures to monetise deficits and long terms in office for central bank officials were all designed to overcome the problems that had been associated with discretionary policy-making. And empirical work provided support for a negative relationship between average inflation and the degree of independence enjoyed by a country's central bank (Bade and Parkin, 1984; Cukierman, 1992; Alesina and Summers, 1993).

Central bank independence was often criticised as inconsistent with democratic accountability. This was not an issue in countries such as Australia, New Zealand, Canada and the United Kingdom (all early adopters of inflation targeting) in which the inflation target was either set by the elected government or jointly negotiated by the central bank and the elected government. It was, and possibly still is, an issue with central banks such as the European Central Bank (ECB), as the ECB can translate its formal mandate (price-level stability) into operational terms (inflation below but near 2 per cent) and has only a weak system of accountability.

\section{Independence and the Fiscal Dimension}

Almost all discussions of central bank independence took for granted the assumption that a suitably independent central bank could achieve its inflation targets. However, monetary policy independence requires fiscal cooperation - one cannot take it for granted that an independent central bank will be able to control inflation unless certain fiscal preconditions are satisfied. Because many central banks over the past two years have engaged in policies that have clear fiscal dimensions, there is a need to re-examine the fiscal conditions supporting central bank independence and to ask whether the arguments in support of such independence still apply.

I will focus on two distinct questions relevant for considering central bank independence and fiscal policy. First, is the concept of central bank independence meaningless without fiscal acquiescence? And second, does central bank independence forgo potential gains from monetary and fiscal policy coordination?

\section{Is the Entire Concept of Central Bank Independence Meaningless Without Fiscal Acquiescence?}

The answer to the first question is surely yes. Without fiscal acceptance of the goals of low and stable inflation, the central bank will ultimately fail, regardless of its supposed degree of operational independence.

Sargent and Wallace (1981) long ago reminded us that a fiscal policy that fails to set the present discounted value of primary fiscal surpluses at a level consistent with intertemporal budget balance forces the central bank to generate the seigniorage necessary to balance the budget. The central bank can reduce inflation, and potentially keep it low for an extended period, but low inflation today will simply require higher inflation in the future. At best, a central bank's ability to maintain low inflation is temporary - ultimately, fiscal insolvency will force the central bank to finance a primary deficit.

Or, as Ben Bernanke (2005) has expressed it, "No monetary-policy regime, including inflation targeting, will succeed in reducing inflation permanently in the face of unsustainable fiscal policies...."

More recently, proponents of the fiscal theory of the price level argue that the price level must ensure the real value of the government's liabilities are equal to the public's expectations of the present real value of future surpluses including seigniorage. ${ }^{3}$ Essentially, there are two separate

\footnotetext{
${ }^{3}$ For recent discussions, see Cochrane (2010) and Leeper (2010).
} 
equilibrium conditions that must be satisfied at the macro level. First, the real demand for money must equal the real supply of money. Second, a valuation equation for government debt requires that the real value of government liabilities equal the expected present real value of the consolidated government's surpluses.

While the first condition has disappeared from explicit view in most policy models, it still remains in the background and must be satisfied in equilibrium. It is the one we often use when we discuss monetary policy and inflation determination. In standard analysis, the fiscal authority always ensures the second condition is satisfied. If the government increases spending now, it must plan to either reduce future spending or raise current or future taxes.

However, shifts in the demand for money or for debt, if not accommodated, will affect aggregate demand and inflation. For example, if the government increases spending and is not expected to either raise taxes or reduce future spending, the value of the government's outstanding liabilities must fall. This decline forces an adjustment of prices and aggregate spending until the real value of outstanding nominal debt is reduced. This is similar to the adjustment associated with a fall in the demand for money - if the money supply is not reduced, prices eventually rise to reduce the real supply to align with the lower real demand.

So the political economy question is: Who ensures that fluctuations in the demand for either debt or money do not spill over to affect the real economy?

The consequences of failing to respond to such shifts can be severe. In the United States, the monetary errors of the Great Depression arose from a failure to accommodate the rise in real money demand associated with bank failures and financial collapse. The Great Recession has seen a flight to safe government debt, and this needs to be accommodated by an increased supply of debt. This may require fiscal authorities to behave in ways that are far from normal. As Chris Sims (2000, p. 969) has put it, in a crisis, "... fiscal policy must be seen not to be committed to conventional prescripts for good fiscal policy" (italics in original).

\section{Are Potential Gains from Policy Coordination Forgone with Central Bank Independence?}

The literature on central bank independence focused on the benefits of independence - central bank independence almost had the flavour of a free lunch. However, potential costs can arise if an independent central bank is reluctant to coordinate policies with the fiscal authority. In normal times, the central bank should actively adjust policy to neutralise the effects of fiscal shifts on aggregate demand and inflation. In a crisis, cooperation may be necessary to ensure fiscal expansion in a crisis is successful (Cochrane, 2010). Monetary independence need not preclude cooperation, but an independent yet insecure institution might feel reluctant to cooperate for fear that its independence would be called into question.

If a modern financial crisis reflects a flight to government debt, then preventing deflation requires an increase in the supply of government debt - an increase in current and expected future deficits at the current price level. If the Treasury fails to accommodate this increase in demand, the central bank may be limited in its ability to stabilise the economy. For example, if short-term debt and money are perfect substitutes at a zero nominal interest rate, an open market operation in short-term debt would fail to accommodate the increased demand for government liabilities. Quantitative easing is then ineffective.

And credit easing - the purchase of private sector assets or direct lending by the central bank to the private sector - does succeed in expanding government liabilities and can meet the private sector demand for government debt. However, this is another way of saying that it is really a fiscal policy operation.

In the United States, the Fed has been conducting fiscal operations on a large scale, in part because of the very independence enjoyed by the Federal Reserve. This independence allowed it to undertake policies that would have been extremely hard to get through Congress, especially in any timely fashion. The flexibility to act quickly that independence allows can be critical in dealing with liquidity crises when financial markets threaten to freeze up and in addressing systematic risk. 
However, clarity about the fiscal support that might be needed for central bank operations in a crisis is important, though providing this once a crisis is underway can be difficult. Yet the flexibility that independence gives can also threaten the central bank's independence if the respective roles of the central bank and the Treasury are not clearly spelled out prior to the crisis. For example, in the United States where these issues were not clearly recognised prior to the crisis, Congress has rightly questioned the fiscal nature of the Fed's actions.

\section{Improving the Interactions Between Monetary and Fiscal Policy}

In normal times, the central bank must have the independence to conduct monetary policy. This requires fiscal cooperation in ensuring a sustainable fiscal budget. Monetary policy should involve open market operations primarily in short-term government securities to reduce the risk of central bank losses when interest rates rise and to separate monetary policy from debt management policies (Goodfriend, 2011). The fiscal authority should control debt management to affect the size and maturity structure of government debt.

In crises, there is a need for coordination - credit easing policies are fiscal policies, but it can be appropriate for the central bank to undertake such fiscal operations if the monetary authority can respond more quickly. However, this flexibility means the central bank risks political exposure needing to take actions before they are endorsed by elected officials can be a serious long-term threat to the central bank's independence in a system such as that of the United States. It may be less of a concern (and also there may be less of a need for it) in a Parliamentary system when a majority government may be able to respond more quickly. In this case, there is less need for such actions to be carried out by the central bank in such a system.

Nothing is so likely to threaten the independence necessary to ensure good monetary policy than the perception that the central bank is directly allocating credit to the private sector and engaging independently in large-scale policies which have significant distributional and fiscal effects.

Finally, cooperation - just as normal policy - needs to be transparent so that it is clear that actions by the central bank are consistent with its mandate and do not threaten its independence.

\section{REFERENCES}

Alesina, A. and Summers, L. (1993), 'Central Bank Independence and Macroeconomic Performance', Journal of Money, Credit, and Banking, 25 (2), 157-62.

Bade, R. and Parkin, M. (1984), Central Bank Laws and Monetary Policy. Department of Economics, University of Western Ontario, Canada.

Bernanke, B.S. (2005), 'Inflation in Latin America: A New Era?' Speech delivered at the Stanford Institute for Economic Policy.

Cochrane, J. (2010), 'Understanding Policy in the Great Recession: Some Unpleasant Fiscal Arithmetic', NBER Working Paper No. 16087.

Cukierman, A. (1992), Central Bank Strategies, Credibility and Independence. MIT Press, Cambridge, MA.

Goodfriend, M. (2011), 'Central Banking in the Credit Turmoil: An Assessment of Federal Reserve Practice', Journal of Monetary Economics, 58 (1), 1-12.

Kydland, F.E. and Prescott, E.C. (1977), 'Rules Rather than Discretion: The Inconsistency of Optimal Plans', Journal of Political Economy, 85 (3), 473-91.

Leeper, E.M. (2010), 'Monetary Science, Fiscal Alchemy', Federal Reserve Bank of Kansas City Jackson Hole Symposium.

Lohmann, S. (1992), 'Optimal Commitment in Monetary Policy: Credibility versus Flexibility', American Economic Review, 82 (1), 273-86.

Persson, T. and Tabellini, G. (eds) (1990), Macroeconomic Policy, Credibility and Politics. Harwood Academic Publishers, Chur, Switzerland.

Rogoff, K. (1985), 'The Optimal Commitment to an Intermediate Monetary Target', Quarterly Journal of Economics, $100(4), 1169-89$.

Sargent, T. and Wallace, N. (1981), 'Some Unpleasant Monetarist Arithmetic', Federal Reserve Bank of Minneapolis Quarterly Review, 5 (3), Winter, 1-17.

Sims, C.A. (2000), 'Comment on "Three Lessons for Monetary Policy in a Low Inflation Era"', Journal of Money, Credit, and Banking, 32 (4), 967-72. 
Walsh, C.E. (1995a), 'Is New Zealand's Reserve Bank Act of 1989: An Optimal Central Bank Contract?', Journal of Money, Credit and Banking, 27 (4), Part 1, 1179-91.

Walsh, C.E. (1995b), 'Optimal Contracts for Central Bankers', American Economic Review, 85 (1), $150-67$.

Walsh, C.E. (2008), 'Central Bank Independence', in Durlauf, S.N. and Blume, L.E. (eds), The New Palgrave Dictionary of Economics, 2nd edn. Palgrave Macmillan. Available on The New Palgrave Dictionary of Economics Online, at http://www.dictionaryofeconomics.com/article?id=pde2008_C000081.

Walsh, C.E. (2010), Monetary Theory and Policy, 3rd edn. MIT Press, Cambridge, MA. 